\title{
THE 55TH ANNIVERSARY OF PROFESSOR O.R. KOTSYURBENKO
}

\author{
Frolov O.A.1,3, Glagolev M.V. 2,3,4 \\ ${ }^{1}$ V.V. Dokuchaev Soil Science Institut, Moscow, Russia \\ 2 Institute of Forest Science, Russian Academy of Sciences, Uspenskoe (Moscow region), Russia \\ ${ }^{3}$ Lomonosov Moscow State University, Moscow, Russia \\ ${ }^{4}$ Yugra State University, Khanty-Mansyisk, Russia
}

Corresponding authors: m_glagolev@mail.ru

Citation: Frolov 0.A., Glagolev M.V. 2020. The $55^{\text {th }}$ anniversary of professor O.R. Kotsyurbenko // Environmental dynamics and global climate change. V. 11. N. 2. P 88-103.

DOI: $10.17816 /$ edgcc40421

Overview of the famous Ugra scientist Oleg R. Kotsyurbenko's scientific activities is given in connection with his anniversary. In the article presented separate publications by Prof. Kotsyurbenko, for some of them a brief summary. All the works under discussion are divided into two categories: microbiology and ecology. In addition, we are given a brief biography of O.R. Kotsyurbenko and a number of little-known photographs from different periods of his life.

Oleg R. Kotsyurbenko graduated from the Moscow Institute of Chemical Technology DI. Mendeleev, specialty «Technology of microbiological production» in 1987. After that, he worked at the Institute of Microbiology of the Russian Academy of Sciences under the guidance of Academician G.A. Zavarzin and Doctor of biology A.N. Nozhevnikova. O.R. Kotsyurbenko defended a Ph.D. thesis in 1997. Since 1999 he has worked abroad - at the Center for Microbial Ecology (Michigan State University) under the direction of Zeikus and Tiedje. Later he worked at the Max-Planck-Institut für terrestrische Mikrobiologie (Marburg), in the laboratory of R. Conrad. Oleg R. Kotsyurbenko received a contract at the Technical University of Braunschweig in 2003 and worked in the K.N. laboratory Timmis in the group P.N. Golyshin. O.R. Kotsyurbenko defended his doctoral dissertation at Lomonosov Moscow State University in 2005. After that, he moved to work at this university (the Department of Microbiology of the Biological Faculty). He began his teaching career, becoming a professor at Yugra State University in 2014.

Scientific publications Oleg R. Kotsyurbenko are well known. They are represented in leading national journals (Journal of General Biology (Biology Bulletin Reviews), Russian Meteorology and Hydrology, Microbiology, etc.) and in the best international journals (Applied and Environmental Microbiology, Environmental Microbiology, FEMS Microbiology Ecology and other). Microbiological work is mainly devoted to one or two questions, previously rather poorly studied in microbiology. How does methanogenesis occur at relatively low $\mathrm{pH}$ and temperatures? What microorganisms carry it out? Attention is paid to archaean methanogens of high bogs and their interaction with other microorganisms. The works within the framework of ecology are devoted to both natural and anthropogenic sources of methane.

Currently, Oleg R. Kotsyurbenko works in the field of astrobiology (space biology). He actively participates in international conferences (European Astrobiology Net Association (EANA), «Solar Systems Studies»). At the moment, he is talking with his European colleagues and is looking for opportunities to involve Russian scientific groups in joint international astrobiological programs. He takes part in a joint program of Roscosmos-NASA to organize research as part of a new mission to Venus initiated by Russia.

Key words: microbiology, methanogens, ecology, vita, biography

В связи с юбилеем известного югорского ученого Олега Ролландовича Коцюрбенко дается обзор его научной деятельности. Упомянуты отдельные публикации Олега Ролландовича, и для некоторых из них приводится краткое содержание. Все обсуждаемые работы разделены на две категории: микробиология и экология. Кроме того, приводится краткая биография О.Р. Коцюрбенко и ряд малоизвестных фотографий разных периодов его жизни.

Ключевые слова: микробиология, метаногены, экология, биография, жизнеописание 


\section{Используемые сокращения:}

ВНИИ - Всесоюзный научно-исследовательский институт;

ЗаС - Западная Сибирь;

ИНМИ - Институт микробиологии;

МГУ - Московский государственный университет им. М.В. Ломоносова;

м.н.с. - младший научный сотрудник;

МХТИ - Московский химико-технологический институт им. Д.И. Менделеева;

ПоК - «Пороговая» концентрация;

ТБО - твердые бытовые отходы;

УП - удельный поток;

УБВ - уровень стояния болотных вод;

ХаФ - характеристическая функция;

ЮГУ - Югорский государственный университет;

EANA - European Astrobiology Net Association;

FISH - Fluorescent in situ hybridization;

$\mathrm{RC}$ - Rice cluster;

T-RFLP - Terminal Restriction Fragment Length Polymorphism.

C/P - удельная цитируемость (среднее количество ссылок, приходящееся на 1 статью автора);

$\mathrm{C}_{\text {RISC }}$ - количество ссылок на статьи автора в системе РИНЦ;

$\mathrm{C}_{\text {WoS }}$ - количество ссылок на статьи автора в системе Web of Science;

$\mathrm{FR}=\left(\mathrm{IF}_{\mathrm{C}}-\mathrm{IF}\right) / \mathrm{IF}_{\mathrm{C}}$, где $\mathrm{IF}_{\mathrm{C}}$ - средневзвешенный импакт-фрактор журналов, в которых были процитированы статьи автора;

$\mathrm{H}$ - индекс Хирша автора в системе Web of Science;

$\mathrm{H}_{\mathrm{Ac}}$ - индекс Хирша автора в системе РИНЦ без учета его самоцитирований;

$\mathrm{H}_{\mathrm{RISC}}$ - индекс Хирша автора в системе РИНЦ;

$\mathrm{H}_{\mathrm{C}}$ - индекс Хирша автора с учетом цитирований только из ядра РИНЦ;

$\mathrm{IF}_{\mathrm{p}}$ - средневзвешенный импакт-фрактор журналов (в системе РИНЦ), в которых были опубликованы статьи автора;

Top25 - количество статей, опубликованных автором в журналах, входящих в «1-ый квартиль» в системе Web of Science;

$\%_{\text {AC }}$ - процент самоцитирований;

$\%_{\text {сс }}$ - процент цитирований соавторами.

Мое детство, моя юность - вот основа моего научного успеха, в них - сила моей энергии, моего творчества.

А.Л. Чижевский

\section{BBEQEIHLE}

Выдающийся югорский ученый Олег Ролландович Коцюрбенко, имя которого широко известно биологам не только ХМАО, но и всей Западной Сибири, внес значительный вклад в развитие некоторых направлений современной микробиологии. Сменив за свою жизнь несколько научно-исследовательских институтов и высших учебных заведений, успев поработать и Москве, и за границей (в США и Германии), свой нынешний юбилей Олег Ролландович встречает в качестве профессора Югорского государственного университета, отдавая свои знания и богатейший опыт делу воспитания молодых сибирских интеллектуалов.
Чтобы читателю было проще осознать масштаб проф. Коцюрбенко как ученого, в табл. 1 мы суммировали некоторые его наукометрические показатели и решили сравнить их с показателями профессоров соответствующего факультета какого-либо ведущего вуза страны. По очевидным причинам в качестве такового был выбран факультет почвоведения МГУ им. М.В. Ломоносова - именно этот факультет, на наш взгляд, в наибольшей степени соответствует большинству работ, которые ведет в последние годы Олег Ролландович в Югорском университете. Для наглядности фамилии в списке упорядочены аналогично тому, как это делается одним из способов в РИНЦ: по убыванию индекса Хирша (а при равенстве этих индексов - по убыванию числа ссылок).

\footnotetext{
1. Кленская И.В. 1985. В солнечном ритме (А. Чижевский). М.: Знание. С. 28. - Цит. по [Ягодинский, 1987, с. 12, 307].
} 
Таблица 1. Некоторые наукометрические показатели).

\begin{tabular}{|c|c|c|c|c|c|c|c|c|c|c|c|c|}
\hline \multirow{2}{*}{ Профессор') } & \multicolumn{3}{|c|}{ Web of Science ${ }^{3)}$} & \multicolumn{9}{|c|}{ Российский ИнАекс Научного Цитирования (РИНЦ)А) } \\
\hline & $\mathrm{H}$ & $\mathrm{C}_{\text {wos }}$ & Top25 & $\mathrm{H}_{\mathrm{RISC}}$ & $\mathrm{H}_{\mathrm{AC}}$ & $\mathrm{H}_{\mathrm{c}}$ & $\mathrm{C}_{\mathrm{RISC}}$ & $\%_{A C}$ & $\%_{c c}$ & $\mathrm{IF}_{\mathrm{p}}$ & $F_{R}$ & $\mathrm{C} / \mathrm{P}$ \\
\hline Коцюрбенко О.Р. & 18 & 1358 & 15 & 18 & 17 & 16 & 1312 & 6.6 & 21.5 & 2.178 & +0.43 & 29.95 \\
\hline Бобров А.А. & 18 & 1089 & 30 & 21 & 21 & 19 & 1673 & 9.8 & 49.9 & 1.602 & +0.32 & 19.24 \\
\hline Водяницкий Ю.Н. & 13 & 628 & 1 & 29 & 26 & 18 & 3815 & 17.3 & 32.2 & 1.369 & -0.08 & 13.23 \\
\hline Шеин Е.В. & 12 & 403 & 3 & 24 & 23 & 12 & 4785 & 10.9 & 39.1 & 1.048 & -0.20 & 13.46 \\
\hline Красильников П.В. & 9 & 322 & 15 & 14 & 13 & 12 & 771 & 15.3 & 36.4 & 2.222 & -0.13 & 5.91 \\
\hline Ладонин Д.В. & 9 & 211 & 2 & 18 & 18 & 11 & 1409 & 4.8 & 13.1 & 1.413 & -0.26 & 24.50 \\
\hline Лысак Л.В. & 8 & 299 & 2 & 23 & 22 & 11 & 2038 & 12.2 & 35.8 & 1.255 & -0.02 & 11.09 \\
\hline Соколова Т.А. & 8 & 279 & 1 & 20 & 18 & 12 & 2673 & 16.0 & 44.7 & 1.288 & -0.12 & 9.85 \\
\hline Зенова Г.М. & 8 & 271 & 0 & 20 & 19 & 12 & 3559 & 9.9 & 24.8 & 1.272 & -0.29 & 12.95 \\
\hline Копцик Г.Н. & 8 & 263 & 5 & 15 & 13 & 10 & 1216 & 22.6 & 36.5 & 1.114 & +0.19 & 9.83 \\
\hline Манучарова Н.А. & 8 & 234 & 1 & 13 & 12 & 10 & 819 & 14.7 & 31.9 & 1.261 & +0.04 & 6.26 \\
\hline Смагин А.В. & 8 & 220 & 2 & 26 & 21 & 10 & 2841 & 36.4 & 62.7 & 0.941 & -0.07 & 11.84 \\
\hline Рыжова И.М. & 7 & 233 & 4 & 11 & 10 & 8 & 674 & 19.1 & 34.0 & 1.264 & +0.30 & 8.8 \\
\hline Терехова В.А. & 7 & 144 & 2 & 17 & 14 & 9 & 1683 & 23.8 & 41.8 & 0.757 & -0.02 & 6.80 \\
\hline Трофимов С.Я. & 6 & 140 & 1 & 16 & 15 & 9 & 1567 & 5.7 & 32.0 & 1.138 & -0.02 & 9.85 \\
\hline Архангельская Т.А. & 6 & 106 & 2 & 15 & 12 & 8 & 757 & 23.9 & 57.5 & 1.413 & -0.16 & 12.06 \\
\hline Алябина И.О. & 5 & 65 & 0 & 22 & 22 & 7 & 2506 & 6.1 & 27.8 & 0.758 & -0.13 & 17.65 \\
\hline Верховцева Н.В. & 4 & 28 & 0 & 9 & 9 & 5 & 632 & 10.0 & 32.1 & 0.664 & +0.11 & 5.22 \\
\hline Кузнецов М.С. & 3 & 39 & 0 & 14 & 13 & 4 & 1359 & 5.2 & 29.8 & 0.874 & -0.24 & 15.73 \\
\hline Демидов В.В. & 3 & 26 & 1 & 9 & 9 & 4 & 501 & 7.2 & 40.5 & 0.999 & -0.04 & 6.50 \\
\hline Глазунов Г.П. & 2 & 29 & 0 & 10 & 9 & 5 & 812 & 15.8 & 29.3 & 1.066 & -0.17 & 4.83 \\
\hline Трифонова Т.А. & 2 & 4 & 0 & 15 & 14 & 4 & 1367 & 13.2 & 26.0 & 0.476 & -0.03 & 5.13 \\
\hline Пахненко Е.П. & 1 & 1 & 0 & 9 & 9 & 3 & 2029 & 1.7 & 11.6 & 0.587 & -0.19 & 54.74 \\
\hline Егоров В.С. & 0 & 0 & 0 & 9 & 9 & 2 & 1734 & 0.2 & 7.3 & 0.517 & -0.06 & 39.54 \\
\hline
\end{tabular}

\section{Примечания:}

1) Во всех столбцах (за исключением \%АС и \%СС) показатели, большие, чем у О.Р. Коцюрбенко, выделены полужирным шрифтом, а меньшие - менее ярким цветом шрифта, ибо, с наукометрической точки зрения, чем больше значение какого-либо показателя, тем больше вклад данного автора в науку. В столбцах \% АС и \%СС поступили наоборот, поскольку представляется, что реальный вклад в науку зависит от этих показателей обратным образом: чем они меньше, тем, следовательно, больше независимых цитирований работ данного автора (т.е., грубо говоря, чем они меньше - тем лучше!).

2) Если сотрудник кроме должности профессора одновременно занимает какую-либо более высокую должность, например, заместителя декана, то в данную таблицу он не включался.

3) Данные для всех, кроме проф. Коцюрбенко, взяты с официального сайта принятой в МГУ системы ИСТИНА [Садовничий, 2014]: http://istina.msu.ru/ (дата обращения: 02.05.2020). Здесь же отметим, что в табл. возможны мелкие неточности (например, если сотрудник только что перешел на должность профессора, но информацию об этом в ИСТИНу еще не успел внести, то его фамилии в табл. не окажется). Поскольку О.Р. Коцюрбенко в настоящее время не является сотрудником МГУ, то информация в ИСТИНе по нему сейчас может не быть достоверной, в связи с чем использовали информацию с сайта http://www.expertcorps.ru/science/whoiswho/ci86 (дата обращения: 02.05.2020).

4) Данные взяты с официального сайта Научной электронной библиотеки eLIBRARY https://elibrary.ru (дата обращения: 02.05.2020).

Вероятно, нет смысла подробно комментировать эту таблицу, ибо она красноречиво говорит сама за себя. Очевидно, что по большинству позиций О.Р. Коцюрбенко занимает лидирующие позиции даже в сравнении с «эли- той» российской экологии - профессорами факультета почвоведения МГУ. Особо хотим обратить внимание читателей на его высокие значения IFP и FR. По ним нетрудно подсчитать, что IFC $=$ IFP $/(1-\mathrm{FR})=2.178 /(1-0.43) \approx 3.8$. 


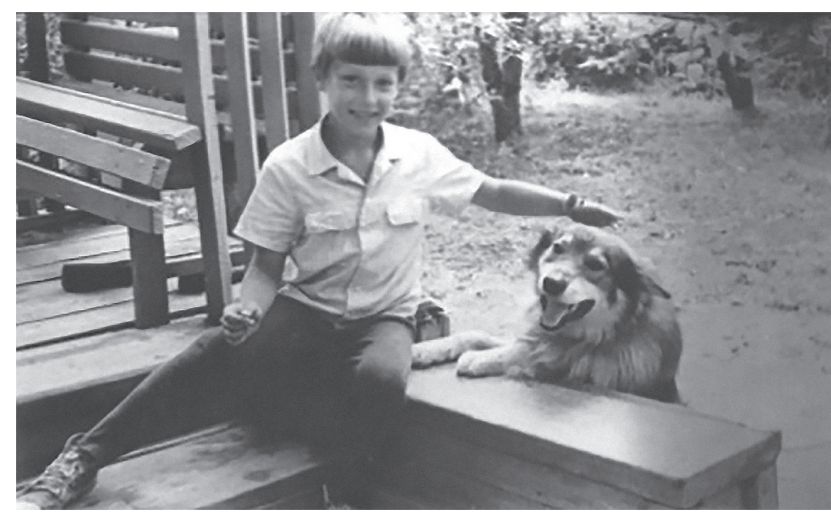

Pnc.1. Лето в деревне около города Ступино (Павелецкое направление).

Это - средневзвешенный импакт-фактор журналов, в которых были процитированы статьи Олега Ролландовича, и это значение намного превышает таковое для любого другого автора из табл. 1. Иначе говоря, работы нашего юбиляра цитируются в наиболее серьезных и уважаемых научных журналах. Более того, он входит в так называемый «список Штерна" наиболее цитируемых российских ученых. Но, наверное, достаточно нудной наукометрии. Основная цель данной статьи: дать краткий обзор научной деятельности проф. Коцюрбенко. Однако при этом, следуя совету Б.С. Горобца [2014, с. 47], «сопроводим... сухую справку о великом ученом хотя бы несколькими эпизодами, по-человечески оживляющими монументальную фигуру...» и приведем некоторые факты его биографии, включая детские годы.

\section{КРАТКАЯ БИОГРАФИЯ О.Р. КОЧЮРБЕНКО}

\section{Детство: врата жизни}

Вынесенные в эпиграф слова Чижевского о значении детских лет для формирования личности заставляют уделить им особое внимание в биографии [Ягодинский, 1987, с. 28, 307]. Это было... Не так давно. На дворе 60-е годы XX-го века. Первый полет человека в космос, высадка на Луну, страны Африки получают

2 В этот список - независимо от области науки - входят те, чьи статьи набрали в Web of Science суммарно не менее 1000 ссылок за все время (условно назовем это «часть А»: 7322 чел.) или хотя бы 100 ссылок за последние 7 лет (часть В: 7754 авторов; многие из них также входят и в «часть А»). Данный список можно найти по адресу http://www.expertcorps.ru/ science/whoiswho/ci86. На 06.05.2020 в «список Штерна» входили 6 сотрудников факультета почвоведения: 3 профессора, 2 заведующих кафедрами и 1 старший научный сотрудник (при этом из их числа двое входили в обе части списка, один - только в «часть А» и трое - только в «В»).

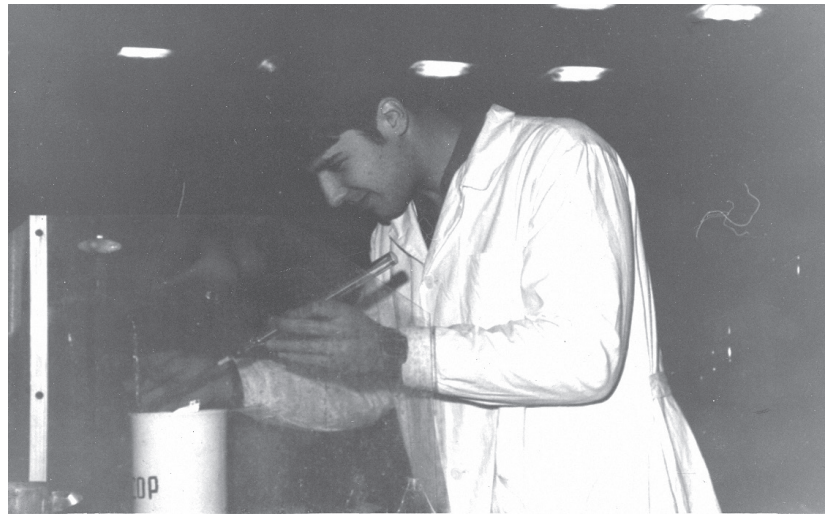

Pnc.2. Лабораторные по химии во время учебы в МХТИ.

независимость, а мир переживает разгар холодной войны. 1965-ый год. Косыгинская реформа и ещё одно куда менее заметное тогда событие - рождение Олега Ролландовича Коцюрбенко.

В первые годы будущий ученый жил недалеко от Останкинской башни. Родители забирали его на выходные в новую квартиру в Медведково, остальное же время он проводил с бабушкой и дедушкой. Интерес к природе и, в частности, к животным был с малых лет. Первое животное в квартире появилось всего на день, когда отец принес из лесной зоны Медведково ежика. Ежика поместили в отдельную комнату, но уже следующим утром его отнесли обратно.

Когда пришло время идти в школу, родители переехали в Бутырский хутор, соседний район с Останкино. Первыми животными, долгое время жившими в квартире, были аквариумные рыбки, которых купил отец, когда маленький Олежек учился в первом классе - гуппи, гурами, меченосцы, сомики. Зная интерес друга к животному миру, школьные товарищи всегда звали с собой, когда их родители покупали живую рыбу на стол. В итоге удавалось дважды получить в подарок живого карпа и живого рака, которых Олег содержал около двух месяцев в ванной, перенося в аквариум, когда приходило время иного использования ванны.

Из животных особенно интересовали земноводные и пресмыкающиеся. Когда в деревне (в Подмосковье, где жили родственники - Рис.1), народ собирался по грибы, Олег с удовольствием шел с ними искать ящериц. На ближайшем пустыре до застройки были пруды и канавы, где с друзьями ловил тритонов, которых потом тоже держал дома. Вообще любил приносить животных, которых сам ловил прудовых рыб, ящериц, тритонов. В конце концов, на птичьем рынке были куплены и содержались в разное время: уж, веретеница, живородящая ящерица, красноухая черепаха, аксолотль, гребенчатые тритоны. В итоге, дома - до 5-6 аквариумов и террариумов, а также стеклянные банки с рыбками, 


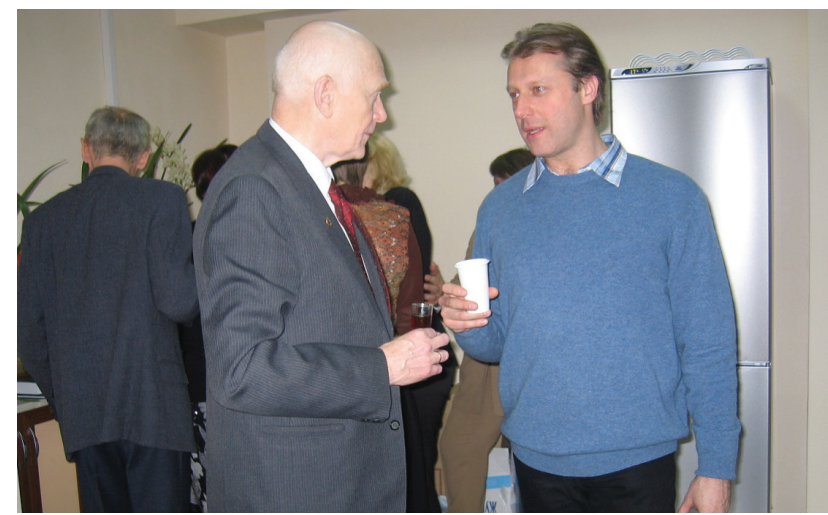

Pис.3. На 75-летнем юбилее академика Г.А. Заварзина. (Олег Ролландович (справа) беседует с юбиляром.).

причем больше привлекали именно прудовые карась, горчак, голец, вьюн и, конечно, ротаны. Аквариумные рыбки, при всей их экзотичности, считались слишком обычными и менее интересными. Из высших животных нравились кошачьи. Собирал про них информацию, делал собственную энциклопедию, помещая в нее текст про каждый вид и приклеивал рисунки с их изображением или рисовал их сам. Любимой книжкой в детстве была книга - «Советы натуралисту-любителю», где описывались все основные животные, которых можно было содержать дома, включая ящериц и змей. Родители поддерживали, не возмущались, за что он им очень благодарен по сей день.

\section{Юность: «врата учености»}

В старших классах стал интересоваться проблемой происхождения жизни, после чего от зоологии постепенно перешел к общей биологии и далее - к микробиологии. Стал собирать статьи и литературу по этой проблематике. Тогда же стал интересоваться поиском жизни во Вселенной. Однажды наткнулся на статью в журнале «Знание - Сила» про возможность существования подледного океана (а в нем - живых организмов!) на спутнике Сатурна Европе, что произвело большое впечатление и желание изучать астробиологическое направление.

Количество аквариумов постепенно уменьшалось, количество книг по интересующим проблемам биологии увеличивалось... В 1982 г. Олег поступил на специальность «Технология микробиологических производств ${ }^{3}$ » в Мо-

3 Впоследствии переименована в «Биотехнологию». А сам МХТИ ныне носит название «Российский химико-технологический университет им. Д.И. Менделеева».

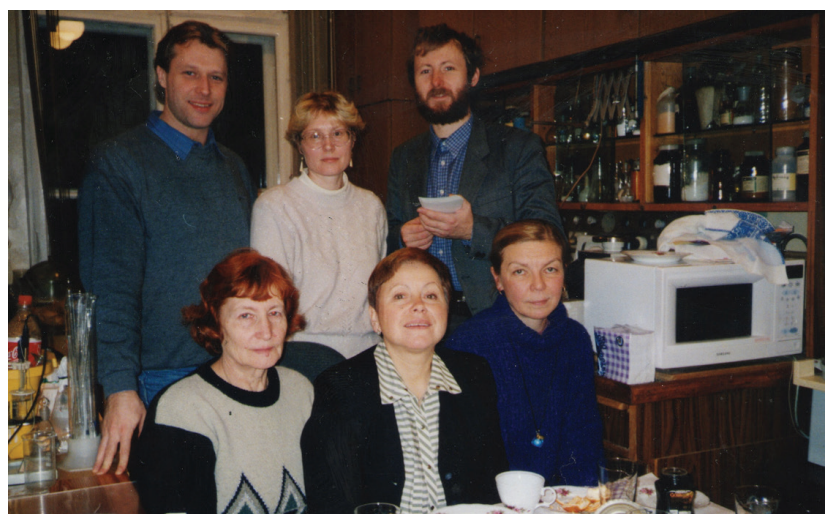

Pnc.4. Основная часть лаборатории А.Н. Ножевниковой (1998 г.). (Слева направо стоят: к.б.н. Коцюрбенко Олег Ролландович, к.б.н. Кевбрина Марина Владимировна, Глаголев Михаил Владимирович; сидят: Некрасова Валерия Куртовна, д.б.н. Ножевникова Алла Николаевна, к.б.н. Паршина Софья Николаевна)

сковский химико-технологический институт им. Д.И. Менделеева (МХТИ). Время самое приятное, как считается: новые друзья, новые знания, новые достижения и пока еще не такая уж большая ответственность (Рис. 2). Окончил институт и собирался поступать в аспирантуру во ВНИИ «Генетика» (Генетики и селекции промышленных микроорганизмов) на «Варшавке», где защищал диплом в лаборатории В. Суходольца под руководством А.С. Миронова (которых Олег Ролландович называет первыми людьми из науки, «приложившими руку», к его становлению как ученого). Но на защите присутствовала Алла Николаевна Ножевникова ${ }^{4}$ и «переманила» в Институт микробиологии (ИНМИ РАН), где он встретился с одним из крупнейших микробиологов тех лет акад. Георгием Александровичем Заварзиным (Рис. 3). В результате Олег оформился в лабораторию к Г.А. Заварзину, в группу 5 Аллы Николаевны (Рис. 4) как стажер на два года.

\section{Молодость: врата на научный Олимп}

Научно-исследовательская работа в Институте микробиологии и преподавание были

4 В то время - к.б.н., ныне - д.б.н.

В дальнейшем лаборатория Заварзина выросла в отдел, а группа Ножевниковой - в одну из лабораторий этого отдела. Впрочем, после известного конфликта, указанная лаборатория была выведена из отдела, и, обретя полную научную самостоятельность (а также дополнительное помещение и совершенно уникального сотрудника - к.б.н. М.В. Чистотина), «расцвела пышным цветом». 


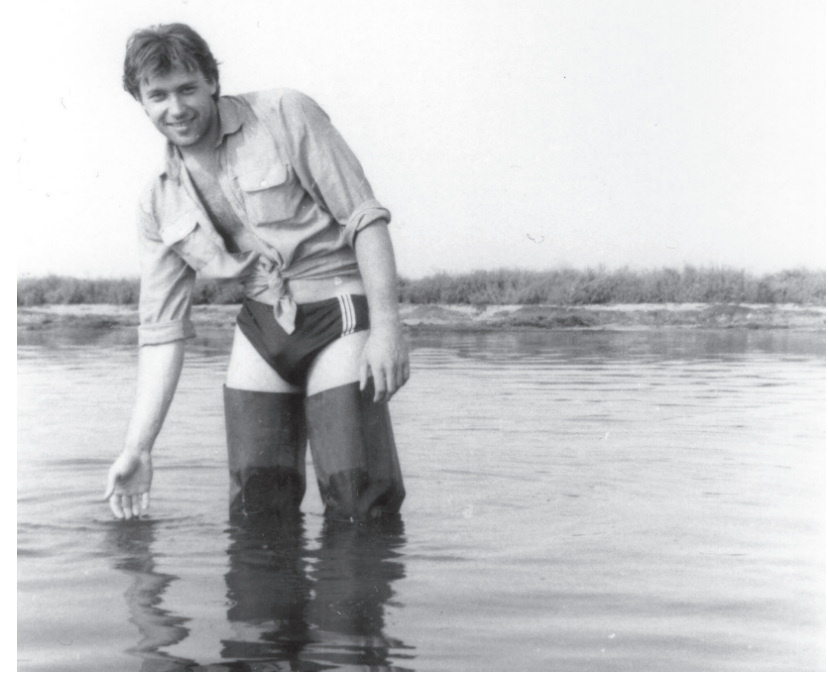

Pnc. 4 На Сиваше в экспедиции Г.А. Заварзина (на следуюший год после прихода в ИНМИ).

построены на особой, «красильниковской» ${ }^{6}$ основе, характеризующейся рядом конкретных организационных и методологических принципов. Это прежде всего масштабность научного поиска, широта и основательность изучения объекта, процесса, явления [Гутина, 1982, с. 60-61]. Продемонстрировав незаурядные способности к научной деятельности, Олег Ролландович по истечении срока стажировки был переведен на должность м.н.с.

А.Н. Ножевникова и Г.А. Заварзин были первыми, кому молодой ученый обязан формированием своих научных взглядов и под руководством которых появились первые серьезные научные достижения (Рис. 5). Его кандидатская диссертация была связана с исследованием процессов метаногенного разложения органического вещества при пониженных температурах. Понятно, что процессы эти шли чрезвычайно медленно (ибо правилу Вант-Гоффа подчиняется не только «чистая химия», но и, разумеется, биохимические реакции). Поэтому иногда приходилось отслеживать динамику процессов практически целый год. В этом помогала природная особенность нашего героя - способность заниматься длительной рутинной работой и постепенно набирать материал, медленно, но верно превращать количество в качество, что отмечал и Г.А. Заварзин. Правда,

6 Н.А. Красильников в разные годы заведовал в Институте микробиологии АН СССР отделами почвенной микробиологии, а также микобактерий и актиномицетов. Олег Ролландович пришел в ИНМИ уже после его смерти, но «красильниковскими» принципами отд. почвенной микробиологии был пропитан еще долгие годы, и многие сотрудники (включая и сотрудников других отделов) успели воспринять их и передать более молодому поколению, к которому относился и Олег Ролландович.

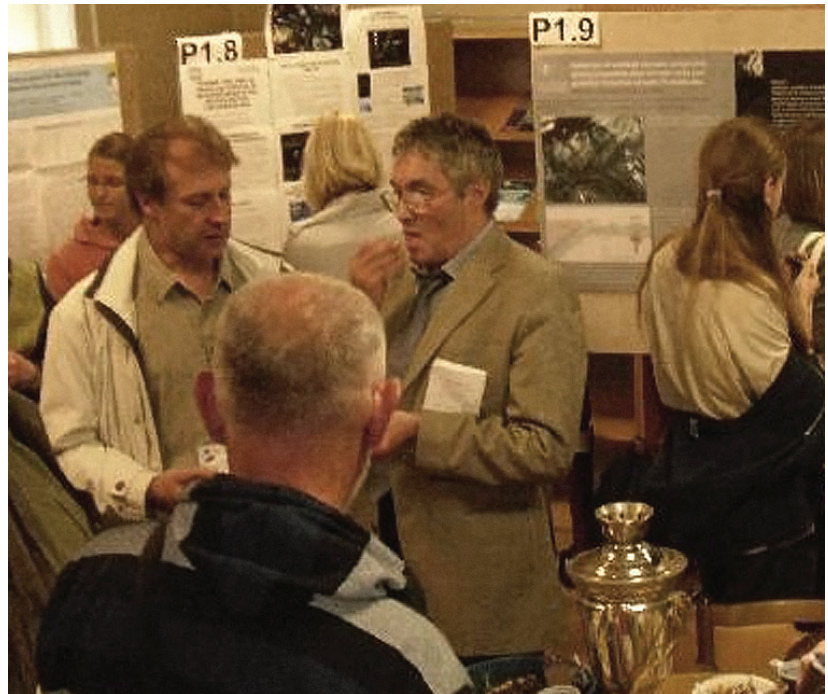

Pnc. 6 С акад. Львом Зеленым на конференции по астробиологии в г. Пущино.

несколько страдала оформительская работа, и кандидатскую диссертацию нынешний юбиляр защитил лишь в 1997 г. - долго готовил, рассчитывал, оформлял, доделывал, перепроверял.

После этого Олег Ролландович начинает активно работать за рубежом. Начиная с 1999 г. - в Центре микробной экологии (Мичиганский Государственный Университет) под руководством Зейкуса (Zeikus) и Тиджи (Tiedje). А потом - в Max-Planck-Institut für terrestrische Mikrobiologie (Марбург), в лаборатории Ральфа Конрада. Последнего можно считать еще одним научным руководителем (помимо А.Н. Ножевникова и Г.А. Заварзина), который значительно повлиял, привнеся немецкий дотошный стиль в работу и просто западную организацию научного процесса. Начиная с 2003 года, герой статьи получил контракт в Техническом Университете Брауншвайга и работал в лаборатории Кена Тиммиса (Timmis) в группе Петра Голышина ${ }^{7}$ Можно сказать, что в это время формирование Олега Ролландовича как ученого завершилось.

В итоге накопилось очень много материала, который пошел в докторскую диссертацию (а она, в отличие от кандидатской, была сделана достаточно быстро и защищена уже в 2005 г.). На написание докторской вдохновил Заварзин, он же и курировал ее вместе с Ножевниковой. Защита прошла в МГУ по предложению Аллы Николаевны и с одобрения Георгия Александровича, так как в МГУ процедура упрощалась и по времени и по организации ${ }^{8}$ В частности, не нужно было

7 Олег Ролландович работал в этой лаборатории до 2010 г.

8 Также существенную роль в выборе места защиты сыграла позиция акад. Иванова - тогдашнего директора ИНМИ РАН. 
писать гигантский «кирпич» - оказалось возможным провести защиту диссертации в виде научного доклада-обзора по серии своих работ (текст диссертации Коцюрбенко [2005] содержит лишь 76 страниц, из которых 6 - это Список работ, опубликованных по теме диссертации). Такая экономия времени была очень важна, поскольку Олег Ролландович в это время работал в Германии в Техническом Университете Брауншвайга (хотя продолжал числиться в ИНМИ и дисциплинированно приезжал на все этапы защиты).

После защиты докторской диссертации, примерно через год, окончательно перешел в МГУ к А.И. Нетрусову (на каф. микробиологии), у которого в лаборатории числился до тех пор, пока тот оставался на посту зав. кафедрой. Однако работал Олег Ролландович практически все это время, все же, в Германии. В 2010 г. он вместе с Виктором Кругловым выиграл большой грант (по программе ТЕМПУС) на модернизацию биотехнологического образования в российских и белорусских вузах по европейским стандартам. Этот проект стал его первой работой, связанной с образованием. В частности, были разработаны учебные программы по биотехнологии, но главное - был получен большой опыт по работе с такими программами, а также произошло знакомство с новыми коллегами из России, Белоруссии, Литвы, Чехии и Германии. После окончания проекта юбиляр остался работать в Германии, где в биоинформационной фирме GeneXplain $\mathrm{GmbH}$ (бывшей одним из участников образовательного проекта) ему была предоставлена частичная ставка9

В 2013 г. один из авторов настоящей статьи предложил Олегу Ролландовичу поехать в возглавляемую им экспедицию по болотам Томской и Новосибирской областей, где рассказал про Югорский государственный университет (ЮГУ) и возможность преподавательской работы там. В экспедиции он работал в отряде, руководимом известным югорским экологом Ильей Владимировичем Филипповым. По-видимому, как в результате бесед Олега Ролландовича с начальником экспедиции, так и его тесного общения с И.В. Филипповым, он отправился в ЮГУ, чтобы на месте ознакомиться с условиями университета. После знакомства с одним из наиболее видных ученых этого университета - д.б.н. Еленой Дмитриевной Лапшиной выбор был окончательно сделан, и Олег Ролландович с 2014 г. начал свою преподавательскую карьеру, став профессором ЮГУ. Но в стенах ЮГУ его деятельность, к

9 Непосредственным руководителем Олега Ролландовича там стал лично Александр Кель - один из основателей компании, переехавший из России (из г. Новосибирска) в Германию на постоянное место жительства. счастью, не ограничивается одним лишь преподаванием. И теперь молодые научные сотрудники имеют возможность перенимать богатый опыт и самобытные методы работы юбиляра в области микробной экологии в связи с изучением ЗападНо-Сибирских болот и полигонов ТБО в ХМАО.

\section{Зрелость: врата в... Космос}

Мы - свидетели величайшего переворота в мировоззрении, участники процесса космизации нашей жизни, производства, научной мысли. В связи с космическими исследованиями образовались новые научные направления, и каждой области естествознания сегодня соответствует свой космический аналог. Так, ныне существует несколько разделов космической биологии [Ягодинский, 1987, с. 54-55]. И в первых рядах отечественных астробиологов видим Олега Ролландовича (Рис. 6).

Параллельно со всеми описанными выше событиями, он никогда не переставал интересоваться астробиологией, которая стала стремительно развиваться (особенно в последнее десятилетие) в США и Европе. В России это направление также развивалось, но с намного меньшей скоростью. Олег Ролландович с энтузиазмом занялся налаживанием контактов с зарубежными учеными для включения России в совместные исследования по астробиологии, стал посещать конференции European Astrobiology Net Association (EANA) и, при поддержке коллег, стал представителем России в Совете EANA, где получил возможность обсуждать совместные направления исследований с европейскими коллегами. Кроме этого, герой статьи стал регулярно участвовать в ежегодных конференциях «Solar Systems Studies» в ИКИ РАН, возглавляемым Львом Зеленым ${ }^{10}$, проявляющим также интерес К астробиологии. В настоящий момент, помимо контактов с европейскими коллегами и поиском возможности вовлечения российских научных групп в совместные международные астробиологические программы, Олег Ролландович участвует в совместной программе Роскосмос-NASA по организации исследований в рамках новой миссии к Венере, инициированной Россией. В этой программе он входит в секцию микробиологии - поиск признаков жизни в облачном слое Венеры. Зная степень настойчивости и методичности проф. Коцюрбенко, можно надеяться, что, если признаки есть, то они, возможно, будут найдены.

\footnotetext{
${ }^{10}$ Акад. Л. Зеленый был директором Института космических исследований РАН в 2002-2017 гг.; ныне он - научный руководитель этого института; в 1992-2002 гг. - научный координатор проекта «Интербол»; являлся научным руководителем российской Лунной программы, проекта «Резонанс», российской части проекта ЭкзоМарс.
} 


\section{HEKOTOPЫE ПУБПИКАUИИ O.P. KOUIOPБEЕКК}

И все-таки, жизнь ученого - в его трудах. Для читателя главный интерес в научной биографии, конечно, представляют наиболее ценные мысли и достижения, составляющие зерно жизни, суть творчества ученого [Ягодинский, 1987, с. 7]. Статьи Олега Ролландовича достаточно хорошо известны, поскольку многие из них были опубликованы не только в ведущих отечественных («Журнал общей биологии», «Метеорология и гидрология», «Микробиология» и др.), но и в лучших международных журналах, ряд из которых входит в так называемый «1-ый квартиль» («Applied and Environmental Microbiology», «Environmental Microbiology», «FEMS Microbiology Ecology» и др.), т.е. представляют собой $25 \%$ лучших журналов в данной отрасли науки. Поэтому здесь хотелось бы обратить внимание читателей на менее известные, но подчас не менее интересные публикации. С другой стороны, было бы неправильным совсем обойти вниманием его лучшие - наиболее цитируемые - статьи (к настоящему времени по версии РИНЦ таковыми являются: [Kotsyurbenko et al., 2004; 2001; 2007]).

\section{Микробиология}

Наверное, было бы логичным представить статьи проф. Коцюрбенко в исторической последовательности. Однако начнем с двух последних его публикаций - [Kotsyurbenko et al., 2019; 2020], поскольку в них Олег Ролландович обобщил свои взгляды на образование метана в природных средах, а также богатый опыт работы с метаногенами. Краткое содержание этих статей поможет читателю войти в проблематику работ нашего героя и составит необходимый для дальнейшего чтения «бэкграунд», тем более, что последняя публикация представляет собой адаптированную к формату журнальной статьи лекцию курса «Современные проблемы биологии», читаемого проф. Коцюрбенко в Югорском университете.

Постановка каждого из направлений работ ученого оригинальна и, как правило, независима от традиционно сложившихся точек зрения, а предлагавшиеся им решения свидетельствуют об умении мобилизовать горы фактов для доказательства защищаемых положений [Ягодинский, 1987, с. 248]. В своих лучших работах (как, впрочем, и почти во всех остальных) Олег Ролландович, в основном, интересовался одним-двумя вопросами, ранее довольно плохо исследованными в микробиологии: как проис- ходит метаногенез (и какие микроорганизмы его осуществляют) при относительно низких pH и температурах. Эти, на первый взгляд, совершенно частные вопросы имеют для специалистов чрезвычайно большое значение в свете глобальной проблемы изменения климата.

Согласно современным представлениям, ведущую роль в потеплении климата играют парниковые газы [Ramanathan et al., 1985; Benestad, 2017; Franz et al., 2018]. Среди них второе место (после диоксида углерода) занимает метан. Главным природным источником $\mathrm{CH}_{4}$ являются болота [Bartlett and Harriss, 1993; Lelieveld et al., 1993; Le Mer and Roger, 2001; Ciais et al., 2013], подразделяющиеся на низинные, переходные и верховые [Masing et al., 2010]. Последние почти всегда являются кислыми и часто встречаются в областях с относительно холодным климатом, например, в Западной Сибири (ЗаС). Площади распространения этих трех типов болот, в общем-то, сравнимы, равно как и интенсивность эмиссии метана из них.

Метан образуется метаногенным сообществом, представляющим собой сложную биологическую систему, микробные группы которого тесно связаны трофическими взаимодействиями. Основными микробными агентами, ответственными за продукцию $\mathrm{CH}_{4}$, являются метаногенные археи, которые подразделяются на три основные трофические группы. Микробные системы переувлажненных земель Западной Сибири играют важнейшую экологическую роль в контексте проблемы парниковых газов и изменения состава атмосферы и климата [Kotsyurbenko et al., 2020]. Но о конкретных археях-метаногенах верховых (да, пожалуй, и переходных) болот и о взаимодействии их с другими микроорганизмами до работ Олега Ролландовича было почти ничего не известно.

Гидрологические условия болот обусловливают отсутствие свободного кислорода (постоянно или хотя бы иногда). Это благоприятствует развитию анаэробных микробных сообществ. В отсутствие иных акцепторов электронов, нежели бикарбонат, конечным продуктом распада органического вещества в болотных экосистемах является метан. В свете проблемы глобального изменения климата это придает болотам особое значение как важным источникам метана. Широко распространенным типом болот являются торфяники, в которых происходит накопление торфа из-за того, что разложение растительных остатков ингибируется анаэробными условиями и/или низкой кислотностью среды. Интенсивность образования метана в болотах зависит от ряда факторов (таких как температура, рН, уровень 
стояния воды, тип растительности) и очень широко варьирует как в пространстве, так и во времени. Наиболее важными предшественниками метана в анаэробных условиях торфяника являются ацетат и $\mathrm{CO}_{2}$. В большинстве исследований предполагается, что важным путем метаногенеза в богатых минеральными веществами осоковых болотах является образование метана из ацетата («ацетокластический путь»: $\mathrm{CH}_{3} \mathrm{COOH} \rightarrow \mathrm{CH}_{4}+\mathrm{CO}_{2}$ ), тогда как в олиготрофных сфагновых болотах важнейшим становится метаногенез при восстановлении $\mathrm{CO}_{2}$ («водород-зависимый» путь: $\mathrm{CO}_{2}+4 \mathrm{H}_{2} \rightarrow$ $\left.\mathrm{CH}_{4}+2 \mathrm{H}_{2} \mathrm{O}\right)$. Олиготрофные торфяники, как правило, характеризуются высокой кислотностью $(\mathrm{pH}<5)$ и содержат весьма малые концентрации минеральных веществ. Представляется, что микробы этих болот имеют специальные метаболические механизмы, позволяющие выживать в бедных растворах, не обладающих буферностью. В целом, сообщество микроорганизмов болотных почв играет существенную роль в биогеохимических циклах и потому критически важно для функционирования болотной экосистемы. Исследования разнообразия и обилия микроорганизмов в болотах быстро развиваются благодаря достижениям в методах молекулярной биологии. Изучение функционирования сообщества болотных микробов и их адаптационных механизмов обеспечивает надежную основу для использования этих микроорганизмов в биотехнологии [Kotsyurbenko et al., 2019]. Однако если классическая микробиология характеризовалась относительно случайным выбором объектов и изучением, опять же, в общем-то, случайных их свойств, то сейчас имеем совершенно иной подход. Причем, особенно ярко он проявляется в микробиологии природных биогеохимических циклов.

Современный этап развития науки вообще и биологии, в частности, характеризуется системным подходом к рассмотрению различных явлений. В концепции иерархического холизма, доминирующего в системном подходе, различные биологические системы образуют иерархическую структуру, в которой элемент одной системы является самостоятельной системой низшего уровня. В любой отдельной системе ключевым является взаимодействие ее компонентов и структура, которая обусловливает устойчивость системы. Результат работы и эффективность функционирования метаногенного микробного сообщества также определяется различными физико-химическими параметрами окружающей среды. Применение системного подхода к изучению цикла метана в болотных системах Западной Сибири позволяет наиболее полно оценить вертикальные и горизонтальные системные взаимосвязи, определить ключевые элементы и провести комплексный анализ исследуемой проблемы [Kotsyurbenko et al., 2020]. Как же (и какие же) системные взаимосвязи изучались в конкретных микробиологических исследованиях Олег Ролландовича?

В [Kotsyurbenko et al., 2001] исследовалась конкуренция метаногенов и ацетогенов за $\mathrm{H}_{2}$ в анаэробных местообитаниях при разных температурах. Это делалось на строгой основе микробиологической кинетики: для различных психроактивных штаммов изучались такие кинетические параметры, как максимальная скорость потребления водорода $\left(V_{\max }\right)$, константа полунасыщения $\left(K_{\mathrm{m}}\right)$ и «пороговая» концентрация (ПоК) $\mathrm{H}_{2}$, ниже которой микроорганизмы потреблять водород не могут. Изолированные из различных низкотемпературных местообитаний штаммы метаногенов MSB, MSP и гомоацетогены Acetobacterium bakii, A. paludosum, A. fimetarium, $A$. tundrae оказались способны к росту и потреблению водорода при температурах от 4 до $30^{\circ} \mathrm{C}$.

В полном соответствии с теоретическими представлениями кинетики, как ферментативной, так и микробиологической (см., напримep, [Pirt, 1975; Cornish-Bowden, 1976; Keleti, 1986; Bailey and Ollis, 1987]), $V_{\max }$ возрастала с увеличением температуры, конечно, если последняя не достигала слишком высоких значений. Это возрастание было более явным для штаммов метаногенов, чем для A. bakii, но для последней бактерии абсолютные значения $V_{\max }$ при каждой температуре были в $1.3 \div 3.4$ раза выше. $K_{\mathrm{m}}$ также монотонно возрастала с температурой, и $A$. bakii опять характеризовалась более высокими значениями (около 190-520 Па $\mathrm{H}_{2}$ ), чем метаногены (50-190 Па Н $_{2}$. А вот для ПоК водорода была обнаружена более интересная температурная зависимость. С уменьшением температуры ПоК непрерывно снижалась в культурах $A$. bakii, A. tundrae и шт. MSB. Но для A. paludosum, A. fimetarium и особенно для шт. MSP, водородный «порог» снова возрастал тогда, когда температура падала ниже $10-15^{\circ} \mathrm{C}$. За исключением шт. MSP при температуре $\leq 10^{\circ} \mathrm{C}$; численные значения ПоК, вообще говоря, были ниже у метаногенов $\left(<2\right.$ Па $\left.\mathrm{H}_{2}\right)$, по сравнению с гомоацетогенами $\left(<200\right.$ Па $\left.\mathrm{H}_{2}\right)$. Величины $V_{\max }, K_{\mathrm{m}}$ и ПоК в дальнейшем использовались для сравнения конкурентоспособности микроорганизмов (определяемой их кинетическими особенностями) во всем интервале температур. A. bakii выигрывает конкуренцию при высоких концентрациях $\mathrm{H}_{2}$, что объясняется наибольшим значением $V_{\max }$. Также эти ацетобактерии вытесняют метаногена MSP в условиях сочетания 
низкой температуры с низкой концентрацией водорода. Однако, все же способность метаногенов конкурировать с $A$. bakii за водород возрастает при уменьшении концентрации $\mathrm{H}_{2}$, что объясняется меньшими значениями $K_{\mathrm{m}}$ и ПоК у метаногенов [Kotsyurbenko et al., 2001].

Необходимо отметить, что, кроме выполнения чисто экспериментальной работы, Олег Ролландович проводил глубокий теоретический анализ полученных результатов. В частности, им было установлено, что измеренные значения ПоК падают параллельно величинам, теоретически рассчитанным на основе законов термодинамики. Это позволило вычислить критическое значение энергии Гиббса ${ }^{11}$ (приблизительно от -5 до -8 кДж/моль), при котором потребление водорода оказывается возможным как метаногенами, так и гомоацетогенами.

Основным результатом двух других упомянутых выше статей юбиляра (лидеров по количеству полученных ссылок) стало установление того факта, что в кислых торфах широко представлены популяции метаногенных архей как «водород-зависимого» пути, так и ацетокластического. В связи с этим количество «водородзависимого» метана сравнимо здесь с метаном ацетокластическим.

Так, в [Kotsyurbenko et al., 2004] изучались участки мезотрофного кислого (рН 4.2-4.8) торфяника - Бакчарского болота в южной тайге ЗаС. Было показано, что с глубиной возрас-

11 Пусть $p$ - давление, $v$ - объем системы, $U$ - ее внугренняя энергия, $T$ - абсолютная температура, $S-$ энтропия, тогда энергией Гиббса (изобарно-изотермическим потенциалом) называют величину $G=U+p \cdot v-T: S$. Для систем, в которых протекают химические реакции, изменяющие состав самой системы, необходимо учитывать зависимость $G$ не только от термодинамических переменных, но также от числа молей всех составных веществ системы: $G=G\left(p, T, n_{1}, n_{2}, \ldots\right)$, где $n_{i}-$ число молей $i$-го компонента. Очевидно, что энергия Гиббса уменьшается с ростом температуры, но увеличивается с ростом давления. Термодинамические потенциалы (наряду с $G$ к ним относят и $F$ - энергию Гельмгольца, или изохорно-изотермический потенциал) являются характеристическими функциями (ХаФ) в том смысле, что посредством частных производных от них могут быть явно выражены термодинамические свойства системы. По величине характеристических функций можно судить о направлении самопроизвольных процессов и установлении равновесия в системе: величины ХаФ при постоянстве соответствующих параметров не изменяются при равновесных процессах и убывают при неравновесных процессах. Следовательно, самопроизвольные неравновесные процессы уменышают величины $G$ и $F$, которые достигают минимума при установлении в системе равновесия. Измерение термодинамического потенциала системы имеет большое значение для изучения химических реакций и особенно биохимических превращений, т.к. позволяет определить величину полезной работы, энергетические эффекты и возможные направления тех или иных процессов [Рубин, 1991, с. 59, 64-67, 69]. тает доля метана, образующегося по «водородзависимому» пути. Для анаэробного метаногенного микробного сообщества на глубине 30-50 см ниже УБВ оптимальными условиями оказались: температура $20-25^{\circ} \mathrm{C}$ и рН 5.0-5.5. В экспериментах с добавлением 2-бромэтансульфоната, являющегося ингибитором метаногенеза, было установлено, что важными промежуточными продуктами при разложении органического вещества, предшествующего образованию $\mathrm{CH}_{4}$, являются ацетат, фенилацетат, фенилпропионат и капроат. Дальнейшее разложение этих интермедиатов показывает, что 62-72\% метана происходит из ацетата, а 28-38\% - из $\mathrm{H}_{2}+\mathrm{CO}_{2}$. Время оборота [2- $\left.{ }^{14} \mathrm{C}\right]$ ацетата составляло около 2 сут. и соответствовало как раз 60-65\% продукции $\mathrm{CH}_{4}$. Превращение ${ }^{14} \mathrm{CO}_{2}$ в ${ }^{14} \mathrm{CH}_{4}$ соответствовало $35-43 \%$ продукции метана. Причем такое соотношение (примерно 2 : 1) образования $\mathrm{CH}_{4}$ по ацетокластическому и водород-зависимому путям сохранялось, независимо от температуры инкубирования образцов торфа $\left(4,15\right.$ или $\left.25^{\circ} \mathrm{C}\right)$. Как видим, перечисленные выше результаты были получены при помощи относительно простых методик классической и пост-классической микробиологии. Но необходимо отметить, что для работ Олега Ролландовича всегда было присуще использование и самых современных методов.

В частности, структура архейного сообщества определялась в торфяных образцах при помощи T-RFLP-анализа и секвенирования гена 16S rRNA. B результате было показано присутствие представителей группы RC-II, a также семейств Methanomicrobiaceae и Methanosarcinaceae. Кроме того, были обнаружены группы предположительно не-метаногенных архей (group III, RC-IV, RC-V, RC-VI). C помощью метода FISH было показано, что обилие бактерий с глубиной уменьшается (на глубинах от 5 до 55 см ниже УБВ - с $24 \cdot 10^{7}$ до $4 \cdot 10^{7}$ кл./г торфа), тогда как численность архей слегка возрастает (с $1 \cdot 10^{7}$ до $2 \cdot 10^{7}$ кл./г торфа). При этом примерно половина клеток архей принадлежала видам рода Methanosarcina [Kotsyurbenko et al., 2004].

Эти исследования были продолжены и в [Kotsyurbenko et al., 2007], где при разных значениях рН и температуры вновь изучалась структура микробного сообщества архебактерий (и продукция $\mathrm{CH}_{4}$ ими) в образцах из кислого торфяника. Было показано, что при низких рН (3.8) увеличивалась доля метана, образующегося по «водород-зависимому» пути. При этом возрастала роль представителей семейства Methanobacteriaceae (и по-прежнему значительную роль играли микрооргнизмы семейств Methanomicrobiaceae и Methanosarcinaceae). Из исследованных образцов на питательной среде со смесью водорода и 
углекислого газа при рН 4.5 был выделен предположительно новый ацидофильный психротолерантный вид Methanobacterium sp. (в дальнейшем, к сожалению, утерянный).

Наконец, в [Коцюрбенко и др., 2008] география исследований сообществ метаногенных архей была существенно расширена, т.к. в эти исследования было вовлечено болото «Чистое», расположенное, в отличие от Бакчарского болота, уже не в южной, а в средней тайге Западной Сибири. К сожалению, как отмечали Янин и Филиппов [2016], опубликованная сначала в нерецензируемом общеэкологическом сборнике, а потом - в малоизвестном региональном журнале, эта работа не привлекла хоть скольконибудь значительного внимания специалистов.

В совсем недавней публикации [Lokshina et al., 2019], где Олег Ролландович являлся одним из основных соавторов-микробиологов, были описаны лабораторные эксперименты по инкубированию торфа низинного болота с добавлением (и без) ингибитора ацетокластического метаногенеза - фторацетата $\left(\mathrm{FCH}_{2} \mathrm{COONa}\right)$. Эти эксперименты позволили с известной степенью обоснованности построить математическую модель, призванную прояснить участие различных групп бактерий и архей в превращении органического вещества в $\mathrm{CH}_{4}$ и $\mathrm{CO}_{2}$. $\mathrm{K}$ окончанию инкубирования содержание метана в воздушной фазе флаконов было в 2.6-3.1 раз больше, чем $\mathrm{CO}_{2}$, а величины $\mathrm{pH}$ раствора находились между 6.5 и 7.0. Математическое моделирование динамики изменения концентраций $\mathrm{CH}_{4}, \mathrm{CO}_{2}$ и их изотопного состава показало, что метан образовывался, главным образом, по ацетокластическому пути, субстрат для которого поставлял гомоцетогенез. «Водород-зависимый» путь играл незначительную роль. Разумеется, добавление ингибитора подавляло ацетокластический путь и, фактически, приводило к переключению пути метаногенеза на «водород-зависимый». Интересным наблюдением явилось то, что образующееся количество $\mathrm{CH}_{4}$ очень сильно различается в индивидуальных повторностях - в разных флаконах, в которые помещался торф, отобранный на одном и том же болоте. Надо сказать, что широкая вариабельность повторностей довольно часто встречается при изучении природных систем. Но как объяснить ее? «Кривыми руками» микробиологов или «полевиков», отбиравших образцы? Понятно, что участие Олега Ролландовича в описываемой работе делает такое предположение почти совершенно бессмысленным. Тогда чем же еще? Условиями транспортировки? Хранения? При помощи математического моделирования было показано, что наблюдаемый разброс выхода метана может быть вполне описан если предположить, что в разных флаконах были разные начальные условия - исходные концентрации целлюлозы, ацетата, метана, $\mathrm{CO}_{2}$ и биомассы микробов. Различие в начальных условия, согласно математической модели, приводило и к разнице в соотношении количеств $\mathrm{CH}_{4}$, образующегося по ацетокластическому и «водород-зависимому» путям.

\section{Экология}

Как уже было сказано выше (в разд. «Молодость: врата на научный Олимп»), в 2013 г. Олег Ролландович принял участие в экологической экспедиции. И, с этого момента многие его работы стали чисто экологическими, где микробы лишь подразумевались как агенты тех или иных биогеохимических процессов, но собственно методы микробиологии совершенно не применялись. В данном разделе рассмотрим именно эти публикации, сразу отметив, что все они посвящены проблеме метана как парникового газа. Однако первая, на наш взгляд, чисто экологическая публикация проф. Коцюрбенко относится к гораздо более раннему периоду его творчества. И хотя речь идет всего лишь о кратких тезисах доклада, представленного на съезд малозначительного национального научного общества, нельзя не вспомнить о них, главным образом в связи с драматической историей, развернувшейся вокруг этой публикации.

Защита новых научных концепций всегда требует от исследователя не только твердости характера, личной смелости и уверенности в правоте своих идей, но и достаточной общественной зрелости [Ягодинский, 1987, с. 249]. К числу ученых с высоким чувством гражданской ответственности относится и О.Р. Коцюрбенко. Одной из иллюстраций этого утверждения могут служить перипетии, развернувшиеся вокруг тезисов Тарасова и др. [2000].

С начала 90-х годов XX-го в. работы по проблеме парниковых газов были развернуты на Бакчарском болоте (Томская область, Бакчарский район, координаты: 56 51' с.ш., 8251' в.д.) недалеко от стационара «Плотниково» Института Почвоведения и Агрохимии СО РАН. Это верховое сфагновое болото является частью Большого Васюганского болота, расположенного в Западно-Сибирской низменности. В экспедиционной работе принимали участие несколько групп исследователей: 1) из Национального института исследования окружающей среды (г. Цукуба, Япония), руководитель - проф. Г. Иноуэ; 2) из ИНМИ РАН (г. Москва), руководитель - д.б.н. Н.С. Паников; 3) из Института почвоведения и агрохимии СО РАН (г. Новосибирск), руководитель - чл.-кор. РАН И.М. Гаджиев; 4) из Мо- 
сковского городского Дворца творчества детей и юношества, руководитель - М.В. Глаголев; 5) с каф. физики и мелиорации почв МГУ, руководитель - проф. Е.В.Шеин. Еще одна группа ${ }^{12}(6)$ из
ИНМИ (руководитель - проф. А.Н. Ножевникова) принимала участие в камеральной обработке образцов. Результаты этих работ суммированы в Табл. 2 [Тарасов и др., 2000].

12 Олег Ролландович входил именно в эту группу.

Таблица 2. Главнейшие результаты, полученные на Бакчарском болоте в XX в. (Тарасов и Ар., 2000).

\begin{tabular}{|l|l|}
\hline группы* & \multicolumn{1}{|c|}{ Резултат } \\
\hline 1 и 2 & $\begin{array}{l}\text { Изучена многолетняя динамика потоков } \mathrm{CH}_{4}, \mathrm{CO}_{2}, \mathrm{H}_{2} \mathrm{O}, \text { а также факторов среды, которые } \\
\text { могут влиять на них: температуры, давления, уровня грунтовых вод, pH, Eh и др. }\end{array}$ \\
\hline 2 и 4 & Получены профили распределения метаногенной активности в толще почвы. \\
\hline 2 и 3 & Установлена взаимосвязь геоботанических характеристик местообитания и эмиссии СН 4. \\
\hline 1 & $\begin{array}{l}\text { Изучены механизмы транспорта метана из почвы в атмосферу: диффузионный, пузырьковый } \\
\text { и посредством растений. }\end{array}$ \\
\hline 4 и 5 & Исследованы теплофизические свойства болотной почвы. \\
\hline 6 & Исследованы водно-физические свойства болотной почвы. \\
\hline 2 и 4 & Из почв с рН 3.5-4.0 были выделены накопительные культуры уникальных метаногенов. \\
\hline 2 и 6 & Изучена температурная зависимость эмиссии $\mathrm{CH}_{4}$ и $\mathrm{CO}_{2}$ в лабораторных условиях. \\
\hline 4 & Построена математическая модель эмиссии $\mathrm{CH}_{4}$. \\
\hline
\end{tabular}

*Примечание: подробнее о каждой группе - см. в тексте.

Как видно из табл., исследования, проводившиеся в районе Бакчарского болота, принесли к концу века многочисленные результаты и, повидимому, представляли собой единственный пример на постсоветском пространстве, когда некоторый природный метангенерирующий объект был бы изучен столь многосторонне и столь подробно. Разумеется, широкие круги научной общественности хотели познакомиться с этими результатами, о чем неоднократно говорили одному из авторов настоящей статьи в те далекие годы. Парадокс, однако, заключался в том, что в отечественной научной периодике результаты указанных работ почти не публиковались - за весь период исследований (до описываемых событий 2000 г.) в российских научных журналах появилось буквально несколько статей ${ }^{13}$, причем все они описывали работы, выполненные до 1996 г. включительно, тогда как основной массив данных был получен, начиная с 1997 г. И дело даже не в количестве статей, а в том, что в них была опубликована лишь малая толика результатов, к тому же, весьма частных. В связи с создавшимся нетерпимым положением несколько молодых сотрудников ИНМИ (и в их числе герой статьи), решили сделать обстоятельный доклад, в котором хотели дать по возможности наиболее подробную картину проведенных ис-

13 Нам известно лишь о [Panikov et al., 1995; 1997; Ефремова и др., 1998]. следований. Это естественное желание вызвало необъяснимое противодействие со стороны некоего Паникова. Всеми силами он пытался не допустить публикации тезисов Тарасова и др. [2000]. В частности, он обратился к Олегу Ролландовичу с недостойным предложением: заявить, что тот этих тезисов не писал, что его подпись на рукописи, посланной в редакцию, была подделана, и, в связи с этим, тезисы публиковать нельзя. Наш герой, таким образом, был поставлен в трудное положение. С одной стороны, подпись, конечно, не была подделана. Но с другой - заполучить себе такого врага... Еще недавно Паников был заместителем директора ИНМИ, и хотя к этому времени он был уже изобличен, снят с должности (сначала зам. директора, а в дальнейшем - и с должности зав. лабораторией), но по каким-то причинам многие его продолжали опасаться. Тем не менее, Олег Ролландович, не убоявшись последствий, проявил высокое гражданское мужество и, хотя и обратился к организаторам конференции с просьбой его фамилию из списка авторов удалить, но, во-первых, мотивировал это тем, что не считает свой вклад достойным соавторства, а, во-вторых, прямо вопреки желанию Паникова, просил организаторов тезисы обязательно напечатать. К счастью, тезисы уже были в печати, остановить издательский процесс было невозможно, и справедливость восторжествовала - фамилия проф. Коцюрбен- 
ко заняла по праву принадлежащее ей место в списке авторов. Однако теперь, после этой драматической истории перенесемся на 13 лет вперед - к следующей «полностью экологической» публикации Олега Ролландовича. Речь идет о [Sabrekov et al., 2016].

Летом 2013 г. при помощи статического камерного метода была изучена эмиссия $\mathrm{CH}_{4}$ из тростниковых болот (т.е. болот с доминированием Phragmites australis) подтайги и лесостепи ЗаС. Полученные медианы удельных потоков $\mathrm{CH}_{4}$ варьировали от 0.08 до 2.7 мг $\mathrm{CH}_{4} \cdot \mathrm{M}^{-2} \cdot \mathrm{yac}^{-1}$. Был проведен анализ факторов, влияющих на эмиссию. Оказалось, что величина эмиссии из тростниковых болот коррелируют только с концентрацией ионов солей в болотной воде и структурой растительного сообщества, скорее всего, также связанной со степенью засоленности вод. Кроме того, было обнаружено, что в тростниковых болотах отношение удельных потоков $\mathrm{CH}_{4}$ и $\mathrm{CO}_{2}$ не зависит от уровня болотных вод, что противоречит закономерности, воспроизводимой большинством математических моделей эмиссии $\mathrm{CH}_{4}$. Эти факты показывают, что (с точки зрения исследования эмиссии метана) тростниковые болота и близкие к ним экосистемы необходимо рассматривать как отдельный тип болотных экосистем, не смешивая его с прочими мезо- и эвтрофными болотами лесостепи и подтайги [Sabrekov et al., 2016].

Важным источником метана также являются небольшие внутриболотные озера. Однако изменения (в пространстве и времени) потоков $\mathrm{CH}_{4}$ из озер, равно как и пробелы в наших знаниях о факторах окружающей среды, контролирующих эти потоки, обусловливают значительную неопределенность глобального бюджета метана. B [Sabrekov et al., 2017] приведены данные измерений удельных потоков (УП) $\mathrm{CH}_{4}$ на небольших озерах при помощи камерного метода и ловушек пузырьков. Полевые исследования были проведены в июле-августе 2014 г. в подзонах средней и южной тайги Западной Сибири. Средние арифметические значения и медианы УП внутриболотных озер (измеренные камерным методом) в первой подзоне составили, соответственно, 0.32 и $0.30 \mathrm{MгCH}_{4} \cdot \mathrm{M}^{2 \cdot \mathbf{q}^{-1}}$, а во вто-

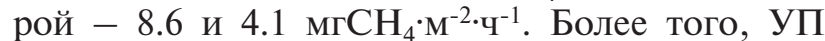
в разных подзонах отличались не только по абсолютным значениям, но и вероятностными распределениями: в средней тайге измерения наилучшим образом описывались при помощи лог-нормального, а в южной тайге - степенного закона. Обнаружение степенного распределения навело авторов на мысль о том, что объяснение существенной вариабельности эмиссии в пределах одного и того же озера (в южной тайге) может быть дано на основе те- ории самоорганизованной критичности. Для анализа как существенных различий в эмиссии, так и влияния факторов внешней среды, была построена новая динамическая математическая модель. Расчеты по ней продемонстрировали хорошее совпадение с величинами УП из озер южной тайги, но для средней тайги совпадение было хуже. Модель показала, что кроме таких хорошо известных факторов, как $\mathrm{pH}$, температура и толщина водяного слоя, в озерах рассматриваемых подзон существенно различается максимальная метан-продуктивность. Кроме того, модель предсказала, что суммарная эмиссия $\mathrm{CH}_{4}$ из конкретного озера может определяться долей заполненного газом порового пространства осадков.

К перечисленным выше работам по природным источникам метана примыкают работы и по его антропогенным источникам. В последние годы Олег Ролландович был руководителем проекта РФФИ, в рамках которого проводились измерения эмиссии $\mathrm{CH}_{4}$ из полигонов захоронения ТБО. Применение камерного метода в этом случае может привести к существенному занижению потока, поскольку полигоны ТБО обычно характеризуются небольшим числом чрезвычайно мощных локальных выходов газа. Действительно, вероятность того, что камерой случайно будет накрыт такой «точечный» источник, чрезвычайно мала ${ }^{14}$. Но грунт между этими локальными выходами может вообще не выделять, а поглощать метан. И если ни один источник в камеру не попал, то измерения приведут к парадоксальному выводу: полигон захоронения ТБО является не источником, а стоком $\mathrm{CH}_{4}$. В связи с этим для измерений на полигонах ТБО в [Terentieva et al., 2017] был разработан метод решения обратной задачи идентификации граничного режима двумерного параболического уравнения диффузииконвекции, а именно: определения удельного потока метана из почвы по измерениям его концентрации в приземном слое атмосферы. Актуальность этой постановки связана с отсутствием сравнительно дешёвых и качественных методов для репрезентативной оценки удельного потока метана из таких его источников, которые характеризуются существенной пространственной

14 Пусть, например, мы имеем небольшой квадратный полигон с площадью $S\left(S \sim 10^{4}\right.$ м), на котором расположено $N$ локальных источников метана. Для простоты будем считать, что они распространены равномерно. Пусть измерение проводится $\mathrm{k}$ раз камерой, основание которой представляет собой круг диаметром $D(D \approx 0.45$ м). Было проведено статистическое моделирование для $N=25$ и $k=50$ (такие значения представляются типичными, хотя оценка для $N$ может быть ошибочной). Оно показало: вероятность того, что хотя бы один источник в результате этих измерений будет накрыт хотя бы одной камерой, составляет лишь $2 \%$. 
и временной неоднородностью эмиссии. Понятно, что поле концентраций в атмосфере формируется при участии всех источников, причем в значительной степени - под влиянием наиболее мощных (т.е. в данном случае именно под влиянием тех локальных выходов газа, которые «не замечает» камерный метод).

В августе 2015 года с помощью метода обратной задачи был измерен удельный поток метана из полигонов захоронения твердых бытовых отходов Сургута и Ханты-Мансийска. Полученные значения УП варьировали от 0.3 до 5.8 $\mathrm{rCH}_{4} \cdot \mathrm{M}^{-2} \cdot \mathrm{q}^{-1}$. Наибольшее значение УП получено для полигона, который продолжает заполняться мусором и не перекрыт слоем грунта, наименьшее - для закрытого полигона небольшой мощности, перекрытого грунтом и поросшего растительностью [Terentieva et al., 2017].

Успех применения метода обратной задачи для измерения эмиссии $\mathrm{CH}_{4}$ на полигонах захоронения ТБО привел к дальнейшему продолжению работ и совершенствованию методики. Так, в [Сабреков и др., 2017] сравниваются уже два подхода к реализации метода обратной задачи для измерения удельного потока метана из полигонов ТБО: лагранжев и эйлеров. Сопоставление, осуществленное по данным, полученным в мае 2017 года на полигонах ТБО Ханты-Мансийска и Сургута, показало, что эти подходы приводят к разным величинам удельного потока и имеют разную чувствительность к входным данным.

\section{СПИСОК ПИТЕРАТУРЫ}

1. Горобец Б.С. 2014. Ядерный реванш Советского Союза: Об истории атомного проекта СССР. М.: КРАСАНД. 352 с. [Gorobets B.S. 2014. Yadernyi revansh Sovetskogo Soyuza: Ob istorii atomnogo proekta SSSR. Moscow: KRASAND. 352 p. (In Russian)].

2. Гутина В.Н. 1982. Николай Александрович Красильников (1896-1973). М.: Наука. 215 с. [Gutina V.N. 1982. Nikolai Aleksandrovich Krasil'nikov (1896-1973). Moscow: Nauka. 215 p. (In Russian)].

3. Ефремова Т.Т., Бажин Н.М., Гаджиев И.М., Ефремов С.П., Махов Г.А. 1998. Особенности метаногенеза на олиготрофных болотах Западной Сибири и оценка сракторов среды в связи с корректной экстраполяцией потоков СН4 на большие территории // Сибирский экологический журнал. Т. 7. С. 563-570. [Efremova T.T., Bazhin N.M., Gadzhiev I.M., Efremov S.P., Makhov G.A. 1998. Osobennosti metanogeneza na oligotrofnykh bolotakh Zapadnoi Sibiri i otsenka faktorov sredy v svyazi s korrektnoi ekstrapolyatsiei potokov SH4 na bol'shie territorii // Sibirskii ekologicheskii zhurnal. Vol. 7. P. 563-570 (In Russian)].

4. Коцюрбенко О.Р. 2005. Метаногенные микробные сообщества из холодных наземных экосистем.

\section{ЗАKกIOUEHИE}

Закончить наш обзор научной деятельности проф. О.Р. Коцюрбенко хотелось бы словами шести выдающихся ученых (д’Арсонваль, Дюпен, Борайль, Ланжевен, де Смитт и Эптон), сказанными хотя и по поводу другого российского исследователя, но в значительной степени подходящими к Олегу Ролландовичу: «Таков в кратких чертах грандиозный размах творческой деятельности... Обширность и глубина трудов профессора... показывает, что свою жизнь с самых юных лет он посвятил зорким наблюдениям за явлениями природы и глубоким размышлениям о них, что всю жизнь, не щадя себя, он работал в лабораториях. Он неутомимый, исключительный по выносливости и творческой энергии человек, истинный труженик на научной ниве, отдавший всего себя... служению высшим... идеалам... Редко, когда на долю одного ученого выпадает счастье подметить, открыть, установить и доказать так много явлений природы, фактов и законов. Профессор... начал свою научную деятельность очень рано... Сейчас... он вступает в самый плодотворный для ученого возраст. Поэтому мы вправе ждать от этого гениального натуралиста еще замечательных открытий» ${ }^{15}$.

${ }^{15}$ Цит. по [Ягодинский, 1987, с. 268].

Дисс... докт биол. н в форме научного доклада. Москва. [Kotsyurbenko 0.R. 2005. Metanogennye mikrobnye soobshchestva iz kholodnykh nazemnykh ekosistem. Diss... Doct. Biology Sciences (the form of a scientific report). Moscow. (In Russian)].

5. Коцюрбенко О.Р., Да Сильва А.П., Глаголев М.В. 2008. Метаногенное сообщество микроорганизмов из олиготрофного болота «Чистое» (Западная Сибирь): Данные предварительного изучения и перспективы // Динамика окружающей среды и глобальные изменения климата. T.1. № S1. C. 136-140. [Kotsyurbenko O.R., Da Silva A.P., Glagolev M.V. 2008. Methanogenic microbial community from the peat bog «Chistoe» (West Siberia): prelimirarly data and perspectives // Environmental dynamics and global climate change. V. 1. No. S1. P. 136-140].

6. Рубин А.Б. 1991. Термодинамика биологических процессов. М: Изд-во МГУ. 290 с. [Rubin А.В. 1991. Termodinamika biologicheskikh protsessov. Moscow: Izdvo MGU. 290 p. (In Russian)].

7. Сабреков А.Ф., Терентьева И.Е., Глаголев М.В., Коцюрбенко 0.Р. 2017. Обратное моделирование как метод измерения эмиссии метана из полигонов ТБО: сравнение различных подходов // Материалы Пятой Националь- 
ной научной конференции с международным участием «Математическое моделирование в экологии». Пущино: ИФХиБПП РАН. С. 187-188. [Sabrekov A.F., Terent'eva I.E., Glagolev M.V., Kotsyurbenko O.R. 2017. Obratnoe modelirovanie kak metod izmereniya emissii metana iz poligonov TBO: sravnenie razlichnykh podkhodov // Materialy Pyatoi Natsional'noi nauchnoi konferentsii s mezhdunarodnym uchastiem «Matematicheskoe modelirovanie v ekologii». Pushchino: IFKhiBPP RAN. P. 187-188. (In Russian)].

8. Садовничий В.А. (ред.). 2014. Интеллектуальная система тематического исследования научно-технической информации (ИСТИНА). Москва: Изд-во МГУ. 262 с. [Sadovnichii V.A. (ed.). 2014. Intellektual'naya sistema tematicheskogo issledovaniya nauchno-tekhnicheskoi informatsii (ISTINA). Moscow: Izd-vo MGU. 262 p. (In Russian)].

9. Тарасов А.Л., Глаголев М.В, Коцюрбенко О.Р. 2000. Совместные российско-японские исследования проблемы парниковых газов на стационаре «Плотниково» в Западной Сибири // Тезисы докладов III-его съезда докучаевского общества почвоведов. Суздаль. С. 164. [Tarasov A.L., Glagolev M.V, Kotsyurbenko O.R. 2000. Sovmestnye rossiisko-yaponskie issledovaniya problemy parnikovykh gazov na statsionare «Plotnikovo» v Zapadnoi Sibiri // Tezisy dokladov III-ego s'ezda dokuchaevskogo obshchestva pochvovedov. Suzdal'. P. 164. (In Russian)].

10. Ягодинский В.Н. 1987. Александр Леонидович Чижевский. 1897-1864. Москва: Наука. 304 с. [Yagodinskii V.N. 1987. Aleksandr Leonidovich Chizhevskii. 1897-1864. Moscow: Nauka. 304 p. (In Russian)].

11. Янин М.В., Филиппов И.В. 2016. К 50-летию (и 30-летию научной деятельности) М.В. Глаголева // Динамика окружающей среды и глобальные изменения климата. T. 7. № 2. C. 66-84. [Yanin M.V., Filippov I.V. 2016. The 50th anniversary and 30 years of scientific activity of M.V. Glagolev // Environmental dynamics and global climate change. V. 7. No. 2. P. 66-84.]

12. Bailey J.E., Ollis D.F. 1987. Biochemical Engineering Fundamentals. New York: McGraw-Hill Book Company.

13. Bartlett K.B., Harriss R.C. 1993. Review and assessment of methane emissions from wetlands // Chemosphere. V. 26. P. 261-320.

14. Benestad R.E. 2017. A mental picture of the greenhouse effect. A pedagogic explanation // Theoretical and Applied Climatology. V. 128. P. 679-688. doi: 10.1007/s00704-016-1732-y

15. Ciais P., Sabine C., Bala G., Bopp L., Brovkin V., Canadell J., Chhabra A., DeFries R., Galloway J., Heimann M., Jones C., Le Quéré C., Myneni R.B., Piao S., Thornton P. 2013. Carbon and Other Biogeochemical Cycles // In: Stocker T.F., Qin D., Plattner G-K., Tignor M., Allen S.K., Boschung J., Nauels A., Xia Y., Bex V., Midgley P.M. (eds.), Climate Change: The Physical Science Basis. Contribution of Working Group I to the Fifth Assessment Report of the Intergovernmental Panel on Climate Change. Cambridge: Cambridge University Press.

16. Cornish-Bowden A. 1976. Principles of Enzyme Kinetics. London: Butterworth \& Co.
17. Franz D., Acosta M., Altimir N., Arriga N., Arrouays D., Aubinet M., Aurela M., Ayres E., López-Ballesteros A., Barbaste M., Berveiller D., Biraud S., Boukir H., Brown T., Brümmer C., Buchmann N., Burba G., Carrara A., Cescatti A., Ceschia E., Clement R., Cremonese E., Crill P., Darenova E., Dengel S., D’Odorico P., Filippa G., Fleck S., Fratini G., Fuß R., Gielen B., Gogo S., Grace J., Graf A., Grelle A., Gross P., Grünwald T., Haapanala S., Hehn M., Heinesch B., Heiskanen J., Herbst M., Herschlein C., Hörtnagl L., Hufkens K., Ibrom A., Jolivet C., Joly L., Jones M., Kiese R., Klemedtsson L., Kljun N., Klumpp K., Kolari P., Kolle O., Kowalski A., Kutsch W., Laurila T., de Ligne A., Linder S., Lindroth A., Lohila A., Longdoz B., Mammarella I., Manise T., Jiménez S.M., Matteucci G., Mauder M., Meier P., Merbold L., Mereu S., Metzger S., Migliavacca M., Mölder M., Montagnani L., Moureaux C., Nelson D., Nemitz E., Nicolini G., Nilsson M.B., de Beeck M.O., Osborne B., Löfvenius M.O., Pavelka M., Peichl M., Peltola 0., Pihlatie M., Pitacco A., Pokorný R., Pumpanen J., Ratié C., Rebmann C., Roland M., Sabbatini S., Saby N.P.A., Saunders M., Schmid H.P., Schrumpf M., Sedlák P., Ortiz P.S., Siebicke L., Šigut L., Silvennoinen H., Simioni G., Skiba U., Sonnentag O., Soudani K., Soulé P., $\quad$ Steinbrecher R., Tallec T., Thimonier A., Tuittila E-S., Tuovinen J-P., Vestin P., Vincent G., Vincke C., Vitale D., Waldner P., Weslien P., Wingate L., Wohlfahrt G., Zahniser M., Vesala T. 2018. Towards long-term standardised carbon and greenhouse gas observations for monitoring Europe's terrestrial ecosystems: a review // International Agrophysics. V. 32. P. 439-455. doi: 10.1515/intag-2017-0039

18. Keleti T. 1986. Basic enzyme kinetics. Budapest: Akadémiai kiadó.

19. Kotsyurbenko O.R., Friedrich M.W., Simankova M.V., Nozhevnikova A.N., Golyshin P., Timmis K., Conrad R. 2007. Shift from acetoclastic to $\mathrm{H} 2$-dependent methanogenesis in a West Siberian peat bog at low $\mathrm{pH}$ and isolation of an acidophilic Methanobacterium strain // Applied and Environmental Microbiology. V. 73. P. 2344-2348.

20. Kotsyurbenko O.R., Glagolev M.V., Sabrekov A.F., Terentieva I.E. 2020. Systems approach to the study of microbial methanogenesis in West-Siberian wetlands // Environmental Dynamics and Global Climate Change. V. 11. No. 1. P. 54-68.

21. Kotsyurbenko O.R., Glagolev M.V., Merkel A.Y., Sabrekov A.F., Terentieva I.E. 2019. Methanogenesis in soils, wetlands and peat // Handbook of hydrocarbon and lipid microbiology Series. Biogenesis of hydrocarbons / A.J.M. Stams and Diana Z. Sousa (Eds.) Springer-Verlag. Berlin Heidelberg. doi: 10.1007/978-3-319-53114-4_9-1

22. Kotsyurbenko O.R., Chin K-J., Glagolev M.V., Stubner S., Simankova M.V., Nozhevnikova A.N., Conrad R. 2004. Acetoclastic and hydrogenotrophic methane production and methanogenic populations in an acidic West-Siberian peat bog // Environmental Microbiology. V. 6. No. 11. P. 1159-1173. 
23. Kotsyurbenko O.R., Glagolev M.V., Nozhevnikova A.N., Conrad R. 2001. Competition between homoacetogenic bacteria and methanogenic archaea for hydrogen at low temperature // FEMS Microbiology Ecology. V. 38. P. 153-159.

24. Le Mer J., Roger P. 2001. Production, oxidation, emission and consumption of methane by soils: a review // European Journal of Soil Biology. V. 37. P. 25-50.

25. Lelieveld J., Crutzen P.J., Bruhl C. 1993. Climate Effects of Atmospheric methane // Chemosphere. V. 26. P. 739-768.

26. Lokshina L., Vavilin V., Litti Y., Glagolev M., Sabrekov A., Kotsyurbenko O., Kozlova M. 2019. Methane Production in a West Siberian Eutrophic Fen is Much Higher than Carbon Dioxide Production: Incubation of Peat Samples, Stoichiometry, Stable Isotope Dynamics, Modeling // Water Resources. V. 46. No. S1. P. S110-S125. doi: 10.1134/S0097807819070133

27. Masing V., Botch M., Läänelaid A. 2010. Mires of the former Soviet Union // Wetlands Ecology and Management. V. 18. P. 397-433. doi: 10.1007/s11273-008-9130-6

28. Panikov N.S., Sizova M.V., Zelenev V.V., Machov G.A., Naumov A.V., Gadzhiev I.M. 1995. Methane and carbon dioxide emission from several Vasyugan wetlands: spatial and temporal flux variations // Ecol. Chem. V. 4. No. 1. P. 13-23.
29. Panikov N.S., Glagolev M.V., Kravchenko I.K., Mastepanov M.A., Kosych N.P., $\quad$ Mironycheva-Tokareva N.P., Naumov A.V., Inoue G., Maxutov S. 1997. Variability of methane emission from west-siberian wetlands as related to vegetation type // Ecol. Chem. V. 6. P. 59-67.

30. Pirt S.J. 1975. Principles of Microbe and Cell Cultivation. Oxford: Blackwell Scientific Publications.

31. Ramanathan V., Cicerone R.J., Singh H.B., Kiehl J.T. 1985. Trace Gas Trends and Their Potential Role in Climate Change // Journal of Geophysical Research. V. 90. P. 5547-5566.

32. Sabrekov A.F., Filippov I.V., Glagolev M.V., Terent'eva I.E., Il'yasov D.V., Kotsyurbenko O.R., Maksyutov S.S. 2016. Methane Emission from West Siberian Forest-steppe and Subtaiga Reed Fens // Russian Meteorology and Hydrology. V. 41. No. 1. P. 37-42.

33. Sabrekov A.F., Runkle B.R.K., Glagolev M.V., Terentieva I.E., Stepanenko V.M., Kotsyurbenko O.R., Maksyutov S.S., Pokrovsky O.S. 2017. Variability in methane emissions from West Siberia's shallow boreal lakes on a regional scale and its environmental controls // Biogeosciences. V. 14. P. 3715-3742.

34. Terentieva I.E., Sabrekov A.F., Glagolev M.V., Kotsyurbenko O.R. 2017. Methane Emission from Municipal Solid Waste Landfills // Russian Meteorology and Hydrology. V. 42. No. 5. P. 327-334.

Поступила в редакцию: 18.06.2020 Переработанный вариант: 04.10.2020 